\title{
The Effect of Neuromuscular Electrical Stimulation
}

\section{Therapy On Stress Urinary Incontinence Recurrence:}

\section{A Randomized Prospective Study}

\author{
Erbil Karaman ${ }^{1 \star}$, Şeyhmus Kaplan ${ }^{2}$, Ali Kolusarı ${ }^{1}$ \\ ${ }^{1}$ Department of obstetric and gynecology, Medical Faculty, V an Yuzuncu Yil University, Van, Turkey \\ ${ }^{2}$ Department of Sports Medicine, Mecial Faculty, Van Yuzuncu Yil University, Van, Turkey
}

\begin{abstract}
The urinary incontinence poses a health problem in community. The standard care for stress urinary incontinence (UI) is surgical therapy. However there are several methods for prevetion of UI recurrence in these patients. Here, we aimed to evaluate the effect of functional electrical stimulation therapy on stress urinary incontinence recurrence in the postoperative period.

Patients who had stress UI and underwent anti-incontinence surgery in our University's Hospital Gynecology Department were randomly divided into two groups. The group 1 received postoperative electrical stimulation of pelvic floor muscles twice in a week (30 minutes) for 4 weeks plus Kegel's exercise and group 2 received only postoperative Kegel's exercise for prevetention of UI recurrence. After completion of therapy, the patients were assesed for urinary recurrence by Wagner's Quality of Life scores Turkish version, pad test and urinary diary.

A total of 48 patients were included in the study. All patients had anti-incontinence surgery of which 39 had transvaginal tape (TVT), 7 had transobturator tape (TOT) procedure an 2 had Burch colposuspension. The main predominant diagnosis was Stress UI in all cases. 20 patients included in group 1 and underwent electrical stimulation with Kegel's exercise and 28 patients included in group 2 which had only Kegel's exercise in postoperative period of one month. The demographic characteristic in terms of age, body mass index, gravidity, parity and co-morbid disease did not show any statistical difference $(\mathrm{P}>0.05)$. The rate of recurrence in UI was significantly lower in Group 1 than Group 2, respectively $(2 / 20,10 \%$ vs $5 / 28,17.8 \%, \mathrm{p}<0.05)$. The mean Qulaity of life scores in group 1 was statistically significantly lower than group $2(7.3 \pm 6.2$ vs $18.4 \pm 6.52, \mathrm{p}<0.05)$. The pad test result did not show any statistical difference $(5.4 \pm 4.2 \mathrm{gr}$ vs $7.4 \pm 6.4 \mathrm{gr}$, $\mathrm{p}>0.05)$.

The electrical stimulation of pelvic floor muscles in postoperative period seems to be effective in prevention of UI recurrence and may be a good strategy to improve the Quality of Life of patients.
\end{abstract}

Key Words: Urinary incontince, electrical stimulation, Kegel's exercise, pelvic floor muscle, Quality of life.

\section{Introduction}

Stres urinary incontinence is defined as an involuntary leakage of urine during an exercise, coughing or any condition that cause increase in intraabdominal pressure by the The World Health Organization (WHO) and the International Continence Society (ICS) (1). It is an important situation for ladies that can cause physical, psycho-social, emotional and economic well-being of affected women and their relatives. And, eventually, it has a great impact on the deterioration of Quality of life like any other chronic debilitation disease including chronic liver-kidney disease or cardiovascular disorders (2). The frequency of urinary incontinence is not well conclusive but it is reported that it can affect up to $25 \%$ of women which can be its highest level at the peri-menapousal age group (3). There are three distinct features of UI in the literature: stress UI, urge UI and mixed UI. And, stress UI is the most commonly seen feature of UI.

The predominant risk factors for development of SUI include age, menopausal status, hormone concentration, body mass index (BMI) and so on, and it is quitely related to the number of gestations/deliveries, pelvic organ prolapsus, chronic pelvic pain, anamnesis of pelvic surgical procedures, diet, and lifestyle (4). The primary cause of Stress UI is the weakening of pelvic floor muscle or the hypermobility of urethra. It is reported that the gold standard treatment option for Stress UI is the sling surgery. The treatment of stress UI is surgical repair of this pelvic floor muscle by vaginal approach and

${ }^{*}$ Corresponding Author: Erbil Karaman, Department of obstetric and gynecology, Medical Faculty, Van Yuzuncu Yil University, Van, 
applying a surgical mesh beneath the urethral structures. The mostly applied procedures are transvaginal tape (TVT) or transobturator tape (TOT) surgeries. There are numerous investigations in the literature that tried to answer the efficacy of these sling surgeries including TVT and TOT; however, no effective results were reached about the efficacy of TVT vs TOT in the therapy of Stress UI (5). The recurrence in incontinence is a crucial point of these surgeries at postoperative lifetime of patients. The conservative therapeutic options for stress UI is based mainly on the training of pelvic floor muscles so as to increase the hammock like effect of suburethral tissue.

There are many options for conservative therapy which include pelvic floor muscle training, electrostimulation, biofeedback, and magnetotherapy (6). The mostly studied conservative method for treatment of Stress UI is pelvic exercises known as Kegel's exercise. The European Association of Urology (EAU) offers the pelvic floor muscle training as a first nonsurgical therapy for UI, whereas neuromuscular elecrtrical stimulation is a rather new method used in the treatment of urinary incontinence. Another new method is magnetic therapy which uses high electromagnetic induction values ( 2 Tesla) with a frequency of $10-50 \mathrm{~Hz}$, which is defined according to the features of urinary incontinence (7). The meachanism of treatment of incontinence is thought to be by the stimulation of neuromuscular structures and muscular contraction of pelvic floor.

Electrical stimulation during pelvic floor muscle training could be beneficial for urinary leakage, sexual function and the muscular contraction-strength by improving the ability of contractibility. The previous studies showed the effectiveness of intravaginal electrical stimulation to improve the urinary incontinence and sexual funscitons. However, despite its effectiveness, Green et al stated that the invasiveness of electrical stimulation via vaginal route has a low rate of patient acceptance and tolerability to the therapy (8). The other form of electrical stimulation which is called transcutaneous electrical stimulation may be more tolerable and acceptable for women with stress UI (9). Innovotherapy is a novel developed externally applied electrical stimulator of muscles and INNOVO ${ }^{\circledR}$ device has been developed to treat the root causes of urinary incontinence and Innovotherapy is the name of the treatment it delivers (10).

The purpose of this study is evaluate the effect of functional electrical stimulation therapy with a novel innovative device on stress urinary incontinence recurrence and Quality of life of patients who underwent anti-incontinence surgery in the postoperative period.

\section{Material and Methods}

This prospective randomized study was conducted in a university hospital's gynecologc clinic between March 2019-June 2020. The patients who had diagnosis of predominantly stress urinary incontinence and underwent anti-incontinence surgery either TVT or TOT operations were recruited. The power analysis to have a required sample size was done with Med-calc system with a power of 0.80 , alpha level of 0.05 , and effect size of $\mathrm{f}=0.917$, it was suggested that a sample size of more than 15 subjetcs per group was adequate. The patients were randomly divided and randomized into two groups after operation as group 1 and group 2. Group 1 patients received functional neuromuscular electrial stimulation to pelvic floow muscle and Kegel's exercise two times in a week for one month at the first postoperative month. Group 2 patients received only Kegel's exercise at first postoperative month for one month. The patients who had followings were excluded from study: patients who had chronic severe diseases, who have cardiac pacemakers, who are pregnant, who had neurological or psychiatric disorders, who had urinary tract infections. The ethical committee of our university approved this study with application number of B.30.2.YYU.0.01.00.00/01.

The diagnosis of urinary incontinence was made according to the physcial examination including stress urimnary leakage test, urinalysis and urodynamic findings before operation. Patients in both group were teached to make Kegel's exercise at least three sets of 10 to 15 repetitions a day for one month during the study period. There were three measurement methods for patients' data analysis. 1) A Bladder diary diagram was used to asses the number of urinary leakage during the three days period. And, the mean of these urinary leakge at the end of last three days of the month were reviewed between groups. 2) The Quality of life(QOL) of patients were assesed by the Wagner's QOL scale at the end of therapy with Turksih version(11, 19). This scale turkish version is given in table 1 . The patients were asked to fill this questionairre, answers were pointed as $0,1,2,3$ and the total score was noted. The score were accepted as followings: $0=$ no 1-28: mild, 29-56: moderate, 57-84 severe leakage or pshyactric deterioration. 3) The pad test was used yo asses the urinary incontinence with an objective manner. The test was applied as 24 hour time frame at the end of the study completion. The test started with an empty 


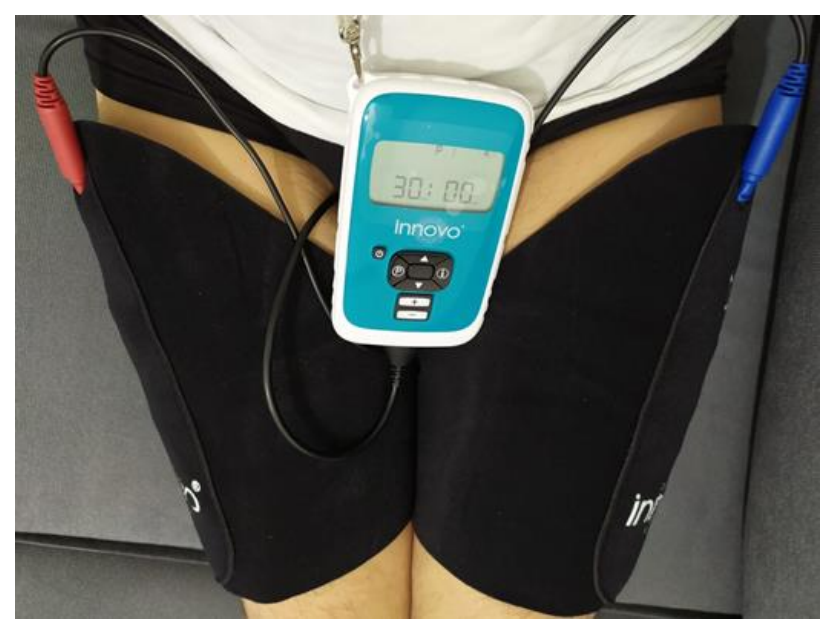

Fig.1. The figure Shows the Application of Innovo Device on a Patient

bladder. Normal daily activities should be performed. The pads should be changed every 4-6 hr during daytime to avoid the evaporation and false positive results. The pads should be wieghed immediately. The results for 24-hr pad test are accepted as follows: Mild (4-20 g/ $24 \mathrm{hr})$, moderate $(21-74 \mathrm{~g} / 24 \mathrm{hr})$, and severe $(>75 \mathrm{~g} / 24 \mathrm{hr})$ incontinence (12).

Intervention: Innovo device was used for external electrical neuromuscular stimulation in group 1 patients. The patients recruited randomly to group 1 was invited to the sports medicine rehabilitaiton center of our hospital when discharged to the home after anti-incontinence surgery. Each patient was asked to sit on a comfortable table and eight external electrodes with a combined stimulating surface region of $1526 \mathrm{~cm}^{2}$ and a current density of $0.03 \mathrm{~mA} / \mathrm{cm}^{2}$, which were applied to the buttocks, outer hips, and the anterior and posterior porximal thighs for a 30min treatment protocol for two times per week lasting for 4 weeks. The figure 1 shows a patient with applied INNOVO device. Subjects were encouraged to change their neutral standing position during the 30min stimulation by changing the pelvic inclination angle slightly and internally/externally rotating the hips. These positional changes altered the current way and patients were able to target the stimulus more anteriorly toward the bladder neck or more posteriorly toward the anal region. A symmetric biphasic pulse was implemented. Figure 1 shows the application of electrodes and the image of device in one of our patients from group 1.

Statistical Analysis: All data analysis was assesed by using the SPSS Statistics package program 20.0 (IBM; Armonk, NY). The Kolmogorov-Smirnov Z-test was used to determine the normality of the data distribution. Data are presented as means \pm standard deviation. Categorical variables were expressed as numbers and percentages. Student's $t$ tests was used for continous variables that showed normal distribution and Mann-Whitney $\mathrm{U}$ tests were used to compare continuous variables which was not normally-distributed. chi-square tests, Fisher's exact tests were used to compare categorical variables. Statistical significance was accepted when $\mathrm{p}$ value is $<0.05$.

\section{Results}

This randomized study included 48 consecutive patients who underwent anti-incontinence surgery in our department and recrutied randomly into two groups according to the given sequential numbers. Group 1 included 20 patients and group 2 included 28 patients. The table 2 shows the demographic and clinical characteristics of the two groups. The mean age of group 1 and 2 were as $42.3 \pm 7.1$ and $41.8 \pm 8.6$, respectively which did not show any statistical significance (p:0.642). The mean parity number, body mass index, smoking status and number of previous vaginal birth did not show any statistical sginificance $(p>0.05)$. The majority of patients in both groups had primary educational level which may have a significant impact on the results of QoL scores (9 in group 1 and 13 in group 2). The stress type UI was the main indication for anti-incontinence surgery in both groups and did not show any significant difference. Regarding the sling operations, TVT was the remarkabely preferred route of operation in both groups. The number of co-morbidities which include hypertension, diabetes or any toher chronic debilitating diseases did not show any statistical diferrence in both groups. The groups were comparable and homogenous in terms of demographic characteristics and clinical features.

Table 3 indicates the clinical outcomes of two groups after neuromuscular electrical stimulation. The recurrence rate seen at the first month after operation showed a statistically significant difference between groups. Group 1 in which electrical neuromodulation with Innovotherapy applied showed a remarkabely lower rate of UI recurrence ( 2 case in group 1 vs 5 cases in group 2, p:0.02). As an objective measure of urinary leakage evaluation, pad test result showed no statistical significance. The 24 hour Bladder diary which was tested at the end of therapy at first month showed a statistical significance and group 1 had lower number of urine leakage as $1.6 \pm 1.2$ when compared to group 2 as $3.2 \pm 1.8$ (p:0.03). When we compare the QoL questionairre scores in both groups, we found a lower scores in group 1 when compared to group 2 which means a higher improvement in the QoL in group 1 in favor of 


\section{Ek: ÜRINER İNKONTINANSLI HASTA YAȘAM KALITESI ANKETI}

Aşağıdaki her cümle idrar kaçırma ile ilgili olup, bu durumun kişinin yaşamını ne kadar etkilediği ölçülmek istenmektedir. Her cümleyi şu şekilde kodlayınız: 0: Hayır, 1: Hafif, 2: Orta, 3: Çok

1. Üzerimi ıslatacağım diye sürekli endişe içindeyim.

2. Başkaları ile bu konuyu konuşurken yüzüm kızarıyor, çok utanıyorum.

3. Aldığım sıvı miktarına sürekli dikkat etmeliyim.

4. Öksüreceğim veya hapşıracağım diye hep heyecan içindeyim.

5. Oturduktan sonra ayağa kalkarken çok dikkat etmem gerekiyor.

6. Yeni bir yere gidince tuvalet nerededir diye merak ediyorum.

7. Kendimi mutsuz hissediyorum.

8. İdrar kaçıııım diye evimden uzun bir süre aynlmak istemiyorum.

9. Bu nedenle kendime olan güvenim sarsılıyor.

10. İstediğim bir şeyi yapamadığımdan dolayı hayal kırıklığına uğruyorum.

11.Başkaları benim üzerimde idrar kokusu duyar diye korkuyorum.

12.İdrar kaçırma sürekli aklımda.

13.Tuvalete sık sık gidip gelmek benim için çok önemlidir.

14. Gülmekten kaçınıyorum.

15.İdrar kaçırmamdan dolayı sürekli bir utanç içindeyim.

16. İdrar kaçırmamdan dolayı ilerdeki her detayı planlamam gerekiyor.

17. Yaşlandıkça daha kötü olacağım diye endişeliyim.

18. Geceleri iyi bir uyku uyumak için çok zorlanıorum.

19. Her an gururum kırılacak, sıkıntıya düşeceğim endişesi içindeyim.

20. Başka insanlarla kucaklaşmaktan kaçınıyorum.

21. İdrar kaçırmam sağlıklı bir insan olmadığım izlenimi veriyor.

22. Beni çaresiz kılıyor.

23. Yaşamdan daha az zevk alıyorum.

24. Zamanında tuvalete yetişemeyeceğim korkusu taşıyorum.

25. Kendi mesanemi kontrol edemiyorum hissine kapilyorum.

26. Sürekli dikkat içinde olmam gerekiyor.

27. Bu benim kıyafet seçimimi sınırlıyor.

28. Seks yaşamım etkilenir diye endişe ediyorum.

(Wagner TH, Patrick DL, Bavendam TG, Martin ML, Buesching DP: Quality of life of persons with urinary incontinence: Development of a new measure. Urology 1996; 47:67-72).

electrical neuromuscular stimulation $(7.3 \pm 6.2$ in group 1 vs $18.4 \pm 6.52$ in group 2, p:0.01).

\section{Discussion}

The present randomized study showed that neuromuscular electrical stimulation of pelvic floor muscles with a novel developed device (INNOVO) at the postoperative period of patients with stress UI is effective in reducing the recurrence rate and imrpove the QoL if patients. The electrical stimulation of pelvic muscles for rehabilitation of stress UI in the literature showed an equivocal results. While some reports have indicated a beneficial aspect of electrical stimulation that is comparable to other non-invasive procedures, there are numerous reports that haven't stated a clear beneficial effect $(13,14,15)$. The most important part of these studdies is coming from their heterogenicity in terms of devices that are used and the study methods that is clearly have impact on the

East J Med Volume:25, Number:4, October-December/2020 
Table 2. Demographic and Clinical Characteristics of The Two Groups

\begin{tabular}{lccc}
\hline Age, years & $42.3 \pm 7.1$ & $41.8 \pm 8.6$ & 0.642 \\
Parity, mean \pm SD & $3.2 \pm 1.6$ & $3.3 \pm 1.4$ & 0.842 \\
Educational level, n/\% & & & \\
Primary education or below & $9 / 20,45 \%$ & $13 / 28,46.4 \%$ & 0.431 \\
Secondary education & $6 / 20,30 \%$ & $8 / 28,28.5 \%$ & \\
Tertiary education or higher & $5 / 20,25 \%$ & $7 / 20,35 \%$ & 0.234 \\
BMI, mean \pm SD & $22.4 \pm 3.2$ & $23.5 \pm 2.6$ & 0.134 \\
Number of previous vaginal birth & $2.8 \pm 1.2$ & $2.6 \pm 1.4$ & 0.542 \\
Menopause, $\mathrm{n} / \%$ & $14 / 20,70 \%$ & $18 / 28,64.2 \%$ & 0.232 \\
Hysterectomy, n/\% & $4 / 20,20 \%$ & $7 / 28,25 \%$ & 0.764 \\
Type of urinary incontinence, n/\% & & & 0.654 \\
$\quad$ Stress UI & $17 / 20,85 \%$ & $24 / 28,85.7 \%$ & 0.142 \\
Mixt type UI(stress+urge) & $3 / 20,15 \%$ & $4 / 28,14.3 \%$ & 0.432 \\
Concomittant operations^, n/\% & $16 / 20,80 \%$ & $24 / 28,85.7 \%$ & 0.340 \\
Co-morbidity\&, n/\% & $9 / 20,45 \%$ & $13 / 28,46.4 \%$ & \\
Anti-incontinence surgery, n/\% & & & \\
$\quad$ TVT & $16 / 20,80 \%$ & $23 / 28,82.1 \%$ & \\
$\quad$ TOT & $3 / 20,15 \%$ & $4 / 28,14.2 \%$ & \\
Burch colposuspension & $1 / 20,5 \%$ & $1 / 28,3.5 \%$ & \\
Smoking status, n/\% & $6 / 20,30 \%$ & $8 / 28,28.5 \%$ & \\
0.763 & & & \\
\hline
\end{tabular}

Table 3. Clinical Outcomes of Two Groups After Neuromuscular Electrical Stimulation

\begin{tabular}{lccc}
\hline & Group 1 $(\mathrm{n}=20)$ & Group 2 $(\mathrm{n}=28)$ & $\mathrm{p}$ value \\
\hline The number of UI recurrence, $\mathrm{n} / \%$ & $2 / 20,10 \%$ & $5 / 28,17.8 \%$ & 0.02 \\
Pad test, gr, mean \pm SD & $5.4 \pm 4.2$ & $7.4 \pm 6.4$ & 0.169 \\
Number of urine leakage at 24 hr bladder & $1.6 \pm 1.2$ & $3.2 \pm 1.8$ & 0.03 \\
diary & & & \\
QoL score, mean \pm SD & $7.3 \pm 6.2$ & $18.4 \pm 6.52$ & 0.01 \\
\hline
\end{tabular}

$\mathrm{P}<0.05$ indicates statistical significance. SD:standard deviation, QoL: Quality of life, UI: Urinary incontinence

success rate of electrical stimulation. The primary treatment of stress UI is a well established data that need surgery for pelvic floor restoration either TVT or TOT operations (5). However, the main issue regarding the postoperative period of these patient is the establishment of rehabilitation program with either Kegel's exercises or strengthening of pelvic muscles with conservative methods in order to prevent the recurrence of these UI symptoms which has a very detrimental effect on the sociol-pshyciatric life of women.

The previous data regarding electrical stimulation of pelvic floor muscle for treatment of UI is based primarily stimulation of perivaginal tissue and while doing this to stimulate the pelvic floor. However, the physcian have to apply the stimulant's applicator into the vagina and this creates a discomfort for the patient and reduces the patient's compliance for the rehabilitation program (14). Another factor is the ability to reach a sufficient intensity of electrical stimulation in order to a valuable contractions in pelvic floor muscles. The main limitator is the vaginal space which limits the electrode size and the creation of a relative high current density. The Innovo system which is a novel, non invasive and practical device has the advantegous of techniqual aspects which is specified as targeted impulses are delivered via conductive pads creating over 180 active contractions per session and the patients can exactly feel their whole pelvic floor musculatures being "lifted" without need of doing any voluntary action (10). On the other hand, one report stated that just one out of nine subjects indicated evidence of a pelvic floor muscles contraction during one session of vaginal neuromuscular electrical stimulation in hook lying, whihc was determined by the evaluation of plevic 
floor (14). So the results of our study which showed beneficial effect of Innovotherapy may be coming from the application surface of our electrode where placed to the buttocks, outer hips, and the anterior and posterior porximal thighs as shown in figure 1.

When we look at the literature about the other conservative therapeutical options for urinary incontinence, there are several methods studied before which include magnetic stimulation and electroacupuncture therapy. $\mathrm{Xu} \mathrm{H}$ et al studied the effectivity of electroacupuncture for women with pure stress UI and conducted a randomized placebo controlled study. They reported that the subjects in the acupuncture group showed greater decreases in ICIQ-SF score and higher ratings in the help they received from the treatment than those in the placebo group (16). However, they didnot compared the acupuncture with pelvic floor muscle training program and this was a pilot study which indeed need to be validated with larger samples. The data regarding a novel therapeutical option which is based on the magnetic stimulation of pelvic floor muscles is equivocal. A study by Wallis MC et al conducted a single-blinded randomized placebo-controlled trial and stated that they did not found any evidence for static magnet to cure or reduce the complaints of UI (17). However, a recent meta-analysis evaluated the effect of magnetic stimulation therapy for urinary incontinence which included 612 patients and stated that the preliminary reports shows magnetic stimulation therapy is an effective treatment option for UI (18). It is obvious that the effectivity of these conservative therapies should be elucidated with the future studies.

Some words should be written about the limitaiton and strength of our study. The main limitaiton is that our sample was not very high eventhough we reached the power analysis. The other limitation is the lack of placebo group which can give a more comprehensive data. The main strength of our study comes from the device which was used in the trial and its novel appliacation position. The other strength may be the homogenous groups of patient in which all of them had stress urinary incontinence and had similar dmeographic variables.

In conclusion, stress urinary incontinence has a very crucial detrimental effect on the health of women and it should be treated in the easiest and effective way. Our study's finding with a novel therapeutic device showed that the electrical stimulation of pelvic floor muscles in postoperative period seems to be effective in prevention of UI recurrence and may be a good strategy to improve the Quality of Life of patients.
Acknowledgement: This study was supported by the Van Yuzuncu Yil University, Department of Scientific Research Project (BAP) with the approval number of TSA-2019-7689.

\section{References}

1. P. Abrams, L. Cardozo, A. Wagg, and A. Wein, Incontinence, ICI-ICS: International Continence Society, Bristol, UK, 6th edition, 2017.

2. Horng SS, Huang N, Wu SI, et al. The epidemiology of urinary incontinence and it's influence on quality of life in Taiwanese middleaged women. Neurourol Urodyn 2013; 32: 371376.

3. Mökinen JI, Grönroos M, Kiilholma PJA et all: The prevalence of incontinence in a randomised population of 5247 adult Swedish women. Int Urogynecol J 1992; 3: 110-113.

4. Hunskaar S, Burgio K, Clark A, et al. Epidemiology of urinary (UI) and faecal (FI) incontinence and pelvic organ prolapse (POP). WHO- ICS International Consultation on Incontinence. 3rd ed. Paris: Health Publications Ltd; 2005.

5. Huang ZM, Xiao H, Ji ZG, Yan WG, Zhang YS. TVT versus TOT in the treatment of female stress urinary incontinence: a systematic review and meta-analysis. Ther Clin Risk Manag 2018; 14: 2293-2303.

6. Weber-Rajek M, Strączyńska A, Strojek K, et al. Assessment of the Effectiveness of Pelvic Floor Muscle Training (PFMT) and Extracorporeal Magnetic Innervation (ExMI) in Treatment of Stress Urinary Incontinence in Women: A Randomized Controlled Trial. Biomed Res Int 2020; 2020: 1019872.

7. Nambiar A. K., Bosch R., Cruz F. et al., "EAU guidelines on assessment and nonsurgical management of urinary incon- tinence," European Urology, vol. 2018; 73: 596-609,

8. Green RJ, Laycock J. Objective methods for evaluation of interferential therapy in the treatment of incontinence. IEEE Trans Biomed Eng 1990; 37: 615-623.

9. Shamliyan TA, Kane RL, Wyman J, et al. Systematic review: randomized, controlled trials of nonsurgical treatments for urinary incontinence in women. Ann Intern Med 2008; 148: 459-473.

10. Maher RM, Caulfield B. A novel externally applied neuromuscular stimulator for the treatment of stress urinary incontinence in women--a pilot study. Neuromodulation 2013; 16: 590-594.

11. Wagner TH, Patrick DL, Bavendam TG, Martin ML, Buesc-hing DP: Quality of life of persons with urinary incontinence: Development of a new measure. Urology 1996; 47: 67-72. 
12. O'Sullivan R, Karantanis E, Stevermuer TL, et al. Definition of mild, moderate and severe incontinence on the 24-hour pad test. BJOG 2004; 111: 859-862.

13. Ashton-Miller JA, Howard D, DeLancey JO. The functional anatomy of the female pelvic floor and stress continence control system. Scand J Urol Nephrol Suppl 2001; 207: 1-7.

14. Bø K, Talseth T, Holme I. Single blind, randomised controlled trial of pelvic floor exercises, electrical stimulation, vaginal cones, and no treatment in management of genuine stress incontinence in women. BMJ 1999; 318: 487-493.

15. Sand PK et al. Pelvic floor electrical stimulation in the treatment of genuine stress incontinence: a multicenter, placebo-controlled trial. Am J Obstet Gynecol 1995; 173: 72-79.

16. Xu H, Liu B, Wu J, et al. A Pilot Randomized Placebo Controlled Trial of
Electroacupuncture for Women with Pure Stress Urinary Incontinence. PLoS One 2016; 11: 0150821

17. Wallis MC, Davies EA, Thalib L, Griffiths S. Pelvic static magnetic stimulation to control urinary incontinence in older women: a randomized controlled trial. Clin Med Res 2012; 10: 7-14.

18. He Q, Xiao K, Peng L, et al. An Effective Meta-analysis of Magnetic Stimulation Therapy for Urinary Incontinence. Sci Rep 2019; 9: 9077.

19. Karan A, Aksaç B, Ayyıldız H, et al. Üriner inkontinanslı hastalarda yaşam kalitesi ve objektif değerlendirme parametreleri ile ilișkisi. Turkish Journal of Geriatrics. Geriatri 2000; 3: 102-106. 